\title{
Propranolol Reduces Risk of Knee or Hip Replacement Due to Osteoarthritis: a Propensity Score Matched Cohort Study-using Data From the Clinical Practice Research Datalink.
}

\section{Georgina Nakafero ( $\nabla$ georgina.nakafero@nottingham.ac.uk)}

University of Nottingham University Park Campus: University of Nottingham https://orcid.org/0000-00023859-7354

\section{Matthew J Grainge}

University of Nottingham University Park Campus: University of Nottingham

\section{Ana M Valdes}

University of Nottingham University Park Campus: University of Nottingham

\section{Nick Townsend}

University of Bath Faculty of Humanities and Social Sciences

\section{Christian Mallen}

Keele University

\section{Weiya Zhang}

University of Nottingham University Park Campus: University of Nottingham

\section{Michael Doherty}

University of Nottingham University Park Campus: University of Nottingham

\section{Mamas A. Mamas}

Keele University

\section{Abhishek Abhishek}

University of Nottingham University Park Campus: University of Nottingham

\section{Research article}

Keywords: $\beta$-adrenoreceptor blockers, osteoarthritis, knee joint replacement and hip joint replacement

DOl: https://doi.org/10.21203/rs.3.rs-670522/v1

License: (c) (i) This work is licensed under a Creative Commons Attribution 4.0 International License. Read Full License 


\section{Abstract}

Objectives To examine the association between $\beta$-blocker prescription and knee or hip total joint replacement (TJR) in a UK primary-care population with incident knee or hip osteoarthritis (OA).

Methods Cohort study using data from the Clinical Practice Research Datalink. Participants aged $\geq 40$ years with incident knee or hip OA, exposed to $\beta$-blockers after OA diagnosis (new-user design), were matched to one control for age, sex, OA location and propensity score (PS) for $\beta$-blocker prescription. Cox-proportional hazard ratios (HRs) and $95 \%$ confidence intervals $(\mathrm{Cl})$ were calculated. The analyses were adjusted for factors that influence health-seeking behaviour, progression of $O A$, and stratified according to $\beta$-blocker classification. Data analysis was conducted using Stata.

Results Data for 6,970 PS-matched $\beta$-blocker exposed and unexposed participants were included. Any $\beta$ blocker prescription was not associated with knee or hip TJR (aHR 1.11; $95 \% \mathrm{Cl} 0.98-1.25)$. However, prescription of lipophilic non-selective $\beta$-blockers having membrane stabilising effects associated with reduced risk of knee or hip TJR (aHR 0.69; 95\% $\mathrm{Cl} 0.52-0.93)$. Of these, there was a protective effect for propranolol (aHR $0.71 ; 95 \% \mathrm{Cl} 0.53-0.95$ ), the commonest prescribed drug in this class. The number needed to treat $(95 \% \mathrm{Cl})$ with propranolol for two years in order to prevent one TJR was $32(23-52)$.

Conclusion Propranolol, a non-selective $\beta$-blocker, reduces the risk of knee and hip TJR. This is consistent with its analgesic effects in other conditions and a randomised controlled trial is required to further evaluate its analgesic potential and safety in $O A$.

\section{Key Message}

What is already known about this subject?

- There is paucity of safe and effective analgesic drugs for OA.

- $\beta$-adrenoreceptor blockers have demonstrated anti-nociceptive effects in several painful conditions.

What does this study add?

- Propranolol, a non-selective $\beta$-blocker, reduces the risk of knee and hip TJR in people with OA.

How might this impact on clinical practice or future developments?

- Propranolol may be used as an analgesic for OA-pain if these findings are confirmed in a clinical trial.

\section{Introduction}

Osteoarthritis (OA) is the commonest form of arthritis and affects approximately 1 in 4 adults older than 45 years in age(1). There is a paucity of effective structure-modifying drug for $\mathrm{OA}$, and, analgesics only have a modest effect size (ES) and may cause troublesome and potentially serious side-effects(2, 3). Consequently, many people undergo total joint replacement (TJR), most commonly at the knee or the hip. An estimated 1.9 million knee or hip TJRs are projected to be performed each year in the USA alone by the year 2030(4). 
Our recent research demonstrated that $\beta$-adrenoreceptor blocking drugs ( $\beta$-blockers) atenolol and propranolol have anti-nociceptive effects on knee and/or hip pain, with the largest ES for propranolol(5). Prior to this, we reported lower opioid consumption and less severe joint pain in people with large-joint lower limb OA prescribed $\beta$-blockers(6), and $\beta$-blocker prescription associated with lower opioid use at day 30 in another study on patients undergoing knee TJR(7). However, this was not confirmed in a study using Osteoarthritis Initiative (OAl) data(8). Whether $\beta$-blockers reduce incidence of TJR in people with OA is not known. In intervention studies, propranolol, a $\beta$-blocker drug, has analgesic benefit on musculoskeletal pain due to fibromyalgia and temporomandibular joint dysfunction and reduces post-operative analgesic requirement(2426). It may be particularly suitable as an analgesic for $O A$ with comorbid anxiety(28), neuropathic pain nonresponsive to NSAIDs and driven by $\beta_{2}$ adrenoreceptor stimulation(18), and those with low catechol-0methyltransferase (COMT) gene activity(29). The latter is of particular mechanistic relevance as $>70 \%$ Caucasians have COMT (158Met) polymorphisms that confers low COMT gene activity(30).

Thus, the objective of this study was to examine whether $\beta$-blocker prescription associates with a lower risk of lower limb arthroplasty in a primary-care population with knee or hip OA.

\section{Methods}

Study Design: Cohort study.

Data source: Data from CPRD were used. Incepted in the year 1987, CPRD is a longitudinal anonymised electronic database containing health records of $>10$ million people in the UK(9). CPRD participants are representative of the UK population in terms of age, sex, and ethnicity(9).

Ethical approval: ISAC of the Medicines and Healthcare products Regulatory Authority (ISAC Reference: 18_227R).

Study population: Age $\geq 40$ years, diagnosed with knee or hip OA between 1st January 1990 and 31st December 2013, at-least 2-year disease and exposure free prior registration in the CPRD before OA diagnosis, and contributing acceptable research quality data in up-to-standard GP practices (Appendix 1).

Exposure: New continuous $\beta$-blocker prescription, defined as $\geq 2$ prescriptions of $\beta$-blockers within a 60 -day period after the first OA diagnosis (new user design).

Unexposed: Participants without a prescription of $\beta$-blocker, or with a single $\beta$-blocker prescription after OA diagnosis date, matched to exposed participants for age at OA diagnosis (5-year age band), sex, OA location (knee or hip) and propensity score (PS) for $\beta$-blocker prescription (Appendix 1).

Start of follow-up (index date): Date of first $\beta$-blocker prescription for the exposed. The duration between OA diagnosis date and first $\beta$-blocker prescription date in the exposed was added to the OA diagnosis date of the matched unexposed to obtain their start of follow-up date. Thus, the exposed and matched unexposed participants had the same duration of OA prior to start of follow-up. This minimised any potential bias due to unequal disease duration prior to start of follow-up in exposed and unexposed participants as the risk of joint replacement increases with duration of $O A(10)$. If this approach was not taken, exposed participants would 
have had longer follow-up with OA prior to cohort entry (time taken to develop a comorbidity for which betablockers may be prescribed) and consequently be at higher risk of outcome.

Outcomes: [1] Knee or hip TJR (primary outcome), [2] knee TJR, and [3] hip TJR.

\section{Exclusion criteria:}

[1] Consultation for the below prior to start of follow-up:

- Conditions causing chronic pain: autoimmune inflammatory rheumatic diseases (rheumatoid arthritis, psoriatic arthritis, ankylosing spondylitis, lupus, polymyalgia rheumatica); gout; radiculopathy; neuropathy; and fibromyalgia.

- Contra-indications for $\beta$-blockers: chronic obstructive pulmonary disease or asthma; peripheral vascular disease; heart block, aortic stenosis, and hypertrophic obstructive cardiomyopathy.

[2] Knee or hip TJR prior to or within 90 days of start of follow-up. Knee or hip TJR within 90 days after start of follow-up were excluded as we do not expect $\beta$-blockers to influence the rate of TJR immediately, and they may have been commenced during a pre-anaesthetic check-up.

End follow-up: Exposed participants were followed up from the index date. Participant follow-up ended at the earliest of date of first outcome, death date, transfer out date, date of last data collection, or study end $(31 / 12 / 2018)$.

Ascertainment of exposure, outcomes and covariates: Read codes and product codes were used to ascertain these factors (Appendix 2).

Statistical Analyses: As participants prescribed $\beta$-adrenoreceptor blocking drugs are likely to have comorbidities, be older and have a high body mass index (BMI), a PS for $\beta$-blocker prescription was calculated using a cumulative logit regression model. Greedy nearest neighbour 1:1 matching, without replacement specifying a maximum calliper width of 0.001 , was undertaken to match the exposed to unexposed participants. Missing values for $\mathrm{BMI}$ and smoking status were categorised as missing data for the purpose of PS matching as people with healthy lifestyle and normal BMI are more likely to have missing data in consultation-based databases such as CPRD where lifestyle and demographic factors are collected opportunistically(11). Mean, standard deviation (SD), $\mathrm{n}(\%)$, and standardised mean difference (SMD) were used to examine the covariate balance between matched exposed and unexposed participants. Any variables that were in imbalance after PS matching were included in the model if the SMD was $>0.10$ as recommended(12).

Hazard ratios (HRs) and 95\% confidence interval ( $\mathrm{Cl}$ ) were calculated for each incident outcome (first Read code for the event) using a Cox proportional hazards model. Covariates that are likely to influence outcomes, e.g. progression of $\mathrm{OA}$, or reflect health-seeking behaviour were included in the Cox model for additional confounder adjustment. These were:

- number of GP consultations for knee or hip injury, non-osteoporotic fractures (defined as fractures in any bone except the femur, distal radius, and vertebrae after the age of 18 years but before the age of 50 
years in women and 60 years in men) prior to start of follow-up,

- number of analgesic prescriptions between the first consultation for knee/hip OA and start of follow-up,

- number of GP consultations, hospital out-patient referrals, hospital admissions in the 12-month period preceding start of follow-up,

- bisphosphonate or glucosamine/chondroitin sulphate prescription in the 12-month period prior to start of follow-up,

- new diagnosis of interphalangeal or thumb base OA, neck or back pain or spinal degenerative diseases after start of follow-up.

These analyses were stratified according to class of $\beta$-blocker drug used namely, $\beta 1$ selective, intrinsic sympathomimetic activity, membrane stabilising effect, and lipophilic properties (low versus high). Number needed to treat (NNT) and 95\% Cl for a 2-year treatment duration were computed using the aHR and survival probability in control group as described previously(13).

Additionally, we performed multiple imputation to handle missing BMI values and smoking status using chained equations as a sensitivity analysis. Demographic factors, relevant diagnoses and prescriptions (Appendix 3), covariates that are likely to influence outcomes or reflect health-seeking behaviour listed above, primary outcome variable, and Nelson-Aalen estimator of baseline cumulative hazard were included in the imputation model as recommended(14). Ten imputed datasets were created to account for random variability(15). PS calculation, matching and Cox regression analyses were undertaken in each imputed dataset. However, we did not find substantial difference between the results with missing values as a dummy category and the imputed values (see Tables S1, S2, and S3 in the supplementary material). Thus, results are only reported with the missing category approach. Data management and analysis were performed in Stata MP v15.

\section{Results}

Data for 13,620 participants exposed to $\beta$-blockers and up to five age, sex and OA location matched unexposed participants ( $n=48,636)$ were ascertained during the study period. Of these, data for 6,970 PSmatched $\beta$-blocker exposed $(n=3,485)$, and unexposed $(n=3,485)$ participants contributing 42,066 personyears of follow-up were analysed (Appendix 2). The majority of participants that had knee OA (81.12\%), more than half our participants were women (57.89\%) and the mean (SD) age at OA diagnosis was 65 (11) years. There was covariate balance between exposed and unexposed after PS-matching on all covariates except for hypertension $(S M D=0.115)$ for which there was minor imbalance (Table 1). Hypertension was included in the model as a covariate to account for the imbalance. After PS matching, unexposed participants had a similar number of consultations with their GP in the preceding 12-months as the exposed, with median (Inter Quartile Range) 11 (6 to 18) and 11 (7 to 18) GP visits, respectively.

Overall $\beta$-blocker prescription was not associated with hip or knee TJR (aHR 1.11; 95\% Cl 0.98-1.25), knee TJR (aHR 1.14; 95\% Cl 0.98 - 1.34) and hip TJR (aHR 1.23; 95\% Cl 0.96-1.57) (Table 2). Similar results were observed on the assessment of beta-blocker classes except for $\beta$-blocker with MSE which showed a reduction in the risk of knee or hip TJR (aHR 0.69; $95 \% \mathrm{Cl} 0.52-0.93)$. The NNT (95\% Cl) to prevent joint replacement at 
2 years follow-up was $32(23-52)$. When data were stratified according to individual drugs, there was a protective effect for propranolol but an increase in the risk of knee or hip TJR for atenolol (Table 3; Fig. 1).

\section{Discussion}

This primary-care based PS-matched study reports that propranolol, a non-selective lipophilic $\beta$-blocker with a membrane stabilising effect and without intrinsic sympathomimetic activity, reduced risk of TJR. This accords with our previous study results where propranolol associated with reduced primary-care consultation for knee OA and knee pain, with reductions of $22 \%$ and $20 \%$, respectively.

The analgesic effects of propranolol may be mediated by directly blocking the $\beta_{2}$ adrenoreceptors on the peripheral nociceptors, dorsal root ganglia, and superficial dorsal horn (16-18), or by indirect effects such as a reduction in the negative affective component of pain (19), regulation of the firing of periaqueductal grey neurons via gamma-Amino butyric acid (GABA)-mediated action, and interfering with the chronic sensitization processes in the rostral ventromedial medulla and locus coeruleus $(20,21)$. Additional mechanisms may include a potentiation of the analgesic effect of sub-therapeutic doses of opioids via dopaminergic and GABA receptor mediated pathways (22). Propranolol also induces infiltrative cutaneous analgesia by blocking the voltage sensitive Sodium ( $\mathrm{Na}+$ ) and Calcium ( $\mathrm{Ca} 2+)$ ion channels, reducing $\mathrm{Na}+$ and Calcium $\mathrm{Ca} 2+$ influxes, and decreasing intracellular cyclic adenosine monophosphate via reduction of adenyl cyclase activity (23) .

Our findings are broadly consistent with the results of some observational studies reporting less severe pain and lower analgesic requirements in people with OA prescribed $\beta$-blockers $(6,7)$. However, they do not accord with those of a study using data from the OAI which reported no difference in pain severity between people prescribed and not prescribed $\beta$-blockers. This may be due to a lack of power, with a modest sample size of 1,168 and only $15 \%$ of participants being exposed to $\beta$-blockers (27).

In the present study, atenolol prescription associated with an increased risk of TJR and this was an unexpected finding given the results of our previous study in which atenolol reduced the risk of incident knee pain. This discordance may be due to the fact that $\beta_{1}$-adrenoreceptor blockade reduces bone resorption and increases bone mineral density (31), and increased bone mineral density associates with an increased risk of TJR (32). Increased bone mineral density is also causally associated with end-stage OA according to a mendelian randomisation study using data from the UK biobank (33). Unlike $\beta_{7}$-adrenoreceptor blockade, $\beta_{2}-$ adrenoreceptor blockade with propranolol does not affect bone resorption or increase bone mineral density (31).

The finding of this study needs to be confirmed in a randomised controlled trial and the safety of propranolol in this population needs to be demonstrated before propranolol may be adopted as an analgesic for $\mathrm{OA}$. The NNT estimated from the present study is high. Strengths of the present study include a large sample size, balanced PS matched exposed and un-exposed groups, and adjustment for other covariates that reflect health-seeking behaviour or are recognised as potential risk factors for TJR in OA. GPs are the first port of call for people with chronic conditions in the UK, and it is extremely unlikely that someone with OA will be seen in a secondary care hospital service, including private settings, without consulting their GP first. Participants with less than two-year registration in the GP practice before the OA diagnosis date were excluded to reduce 
the risk of prevalent cases being included as incident OA. We excluded participants with chronic painful conditions and contra-indications to $\beta$-blockers to minimise confounding by indication that may not be addressed by PS matching. We used a validated definition of primary care diagnosis of knee or hip OA to define the onset of follow-up period $(34,35)$ and did not define our population just on consultation for knee or hip joint pain. Similarly, we used a GP entry of joint replacement surgery to define our outcomes. This has been validated against Hospital Episode Statistics and UK joint registry data and shown to have excellent validity $(36,37)$. Only $60 \%$ of CPRD practices are linked to HES and restricting the dataset to such practices would result in loss of sample size.

However, there are several caveats to this study. Firstly, we used primary care diagnosis of knee or hip OA. This is likely to be later than the onset of symptoms. However, there is no reason to suspect that this delay will differ between exposed and unexposed individuals. The exposure status was based on prescription and not on actual drug taking. However, this will only bias the results towards a null effect. We dichotomised the exposure as present or absent. Further dose response analysis, examining the association between cumulative doses is warranted. We did not use individuals initiating another drug (i.e. active comparator) as controls because there is a hierarchy in the use of different drugs for the treatment of cardiovascular diseases in the UK driven by NICE guidelines. For instance, the NICE guidelines recommend beta-blockers to treat resistant hypertension that has failed to respond to most other anti-hypertensive agents including ACE inhibitors, angiotensin-II receptor blockers, diuretics and calcium channel blockers. On the contrary, they recommend beta-blockers as first-line drugs for treatment of atrial fibrillation, angina and heart failure. Thus, an active comparator study design, even when stratified according to the cardiovascular disease, would introduce greater bias. Primary-care prescriptions in the UK are typically issued for 4 weeks at a time. In this study, exposed participants were required to receive 2 prescriptions in a 60-day period in order to enrich the sample with participants likely to continue with $\beta$-blocker treatment. This potentially introduces immortal time bias as follow-up started with first prescription date. However, both exposed and unexposed participants were required to have at-least 90 days follow-up without TJR, immortal time bias does not affect the validity of our findings. Finally, despite our best efforts residual confounding by indication may remain.

\section{Conclusion}

In summary, we report that the non-selective $\beta$-blocker propranolol reduces the risk of knee or hip TJR. A randomised controlled trial is required to further evaluate the analgesic potential of propranolol in OA.

\section{Abbreviations}

$\mathrm{OA}$ : Osteoarthritis

TJR: Total joint replacement

COMT: Catechol-0-methyltransferase

UK: United Kingdom

ACE: Angiotensin-converting enzyme 
NICE: The National Institute for Health and Care excellence

CPRD: Clinical Practice Research Datalink

HES: Hospital Episode Statistics

GP: General Practice

PS: Propensity score

NNT: Number Needed to Treat

OAl: Osteoarthritis Initiative

$\mathrm{Na}+$ : Sodium

Ca2+: Calcium

GABA: Gamma Aminobutyric Acid

aHR: adjusted Hazard Rate

SMD: Standard mean difference

SD: Standard deviation

BMI: body mass index

Cl: Confidence Interval

ISAC: Independent Scientific Advisory Committee

ES: effect size

USA: United States of America

NSAIDS: Nonsteroidal anti-inflammatory drugs

\section{Declarations}

Ethical approval and Consent to participate.

Approval was obtained from ISAC of the Medicines and Healthcare products Regulatory Authority (ISAC Reference: 18_227R). As this is a database study, there was no contact with participants, hence it did not ascertain consent to participate.

Consent for publication

This manuscript used anonymised patient electronic health data from the CPRD. 
Availability of supporting data.

This study used data from the CPRD. Due to the CPRD data sharing policy, we are unable to share this study's data. However, access to CPRD data can be directly sought from the CPRD.

\section{Competing interest}

This paper presents an independent research funded by the National Institute for Health Research (NIHR) under its Research for Patient Benefit (RfPB) programme (grant reference number PB-PG-0816-20025). The views expressed are those of the author(s) and not necessarily those of the NIHR or the Department of Health and Social Care. AA has received departmental research grants from AstraZeneca, speaker bureau fees from Menarini, scientific meeting support from Pfizer, and author royalties from UpToDate, unrelated to this work. WZ has received honorarium from AstraZeneca and Grunenthal, and speaker fees from BioBarica, Regeneron and Hisun, unrelated to this work. Keele School of Medicine have received funding from Bristol Myers Squibb for advice provided by CMD on primary care recruitment to a non-pharmacological AF study. MD has received honoraria for attending ad hoc advisory boards on gout for Grunenthal and Mallinckrodt, and author royalties from UpToDate, and is an investigator in an AstraZeneca-funded, investigator-led, non-drug study (the 'Sons of Gout' study), unrelated to this work. The other authors have no conflict of interest to declare.

\section{Funding}

The authors disclose receipt of the following financial support for the research, authorship, and/or publication of this article: This paper presents independent research funded by the National Institute for Health Research (NIHR) under its Research for Patient Benefit (RfPB) programme (grant numbers PB-PG-0816-20025 and NIHR-RP-2014-04-026). The views expressed are those of the author(s) and not necessarily those of the NIHR or the Department of Health and Social Care.

Authors' contribution

All authors conceived the study, interpreted results, contributed to and approved the final version of the manuscript. GN performed data analysis supervised by AA and MJG. GN and AA wrote the first draft of the manuscript.

Acknowledgments

none

\section{References}

1. Turkiewicz A, Petersson IF, Björk J, Hawker G, Dahlberg LE, Lohmander LS, et al. Current and future impact of osteoarthritis on health care: a population-based study with projections to year 2032. Osteoarthritis Cartilage. 2014;22(11):1826-32.

2. McAlindon TE, Bannuru RR, Sullivan MC, Arden NK, Berenbaum F, Bierma-Zeinstra SM, et al. OARSI guidelines for the non-surgical management of knee osteoarthritis. Osteoarthritis Cartilage. 2014;22(3):363-88. 
3. Persson MSM, Stocks J, Walsh DA, Doherty M, Zhang W. The relative efficacy of topical non-steroidal anti-inflammatory drugs and capsaicin in osteoarthritis: a network meta-analysis of randomised controlled trials. Osteoarthritis Cartilage. 2018;26(12):1575-82.

4. Sloan M, Premkumar A, Sheth NP. Projected Volume of Primary Total Joint Arthroplasty in the U.S., 2014 to 2030. The Journal of bone and joint surgery American volume. 2018;100(17):1455-60.

5. Nakafero G, Grainge J M, Valdes A, Mallen CD, Zhang W, Doherty M, et al. $\beta$-blockers associate with lower risk of knee osteoarthritis and knee pain consultations in primary care: a PS matched cohort study. Rheumatology. 2021 (accepted for publication 23-Feb-2021). 2021.

6. Valdes AM, Abhishek A, Muir K, Zhang W, Maciewicz RA, Doherty M. Association of Beta-Blocker Use With Less Prevalent Joint Pain and Lower Opioid Requirement in People With Osteoarthritis. Arthritis care \& research. 2017;69(7):1076-81.

7. Starr JB, Backonja M, Rozet I. Beta-blocker Use is Associated with a Reduction in Opioid Use 30 Days After Total Knee Arthroplasty. Pain physician. 2019;22(5):E395-e406.

8. Zhou L, Kwoh CK, Ran D, Ashbeck EL, Lo-Ciganic WH. Lack of evidence that beta blocker use reduces knee pain, areas of joint pain, or analgesic use among individuals with symptomatic knee osteoarthritis. Osteoarthritis Cartilage. 2020;28(1):53-61.

9. Herrett E, Gallagher AM, Bhaskaran K, Forbes H, Mathur R, van Staa T, et al. Data Resource Profile: Clinical Practice Research Datalink (CPRD). Int J Epidemiol. 2015;44(3):827-36.

10. Burn E, Murray DW, Hawker GA, Pinedo-Villanueva R, Prieto-Alhambra D. Lifetime risk of knee and hip replacement following a GP diagnosis of osteoarthritis: a real-world cohort study. Osteoarthritis Cartilage. 2019;27(11):1627-35.

11. Marston L, Carpenter JR, Walters KR, Morris RW, Nazareth I, Petersen I. Issues in multiple imputation of missing data for large general practice clinical databases. Pharmacoepidemiol Drug Saf. 2010;19(6):618-26.

12. Nguyen TL, Collins GS, Spence J, Daurès JP, Devereaux PJ, Landais P, et al. Double-adjustment in propensity score matching analysis: choosing a threshold for considering residual imbalance. BMC medical research methodology. 2017;17(1):78.

13. Altman DG, Andersen PK. Calculating the number needed to treat for trials where the outcome is time to an event. Bmj. 1999;319(7223):1492-5.

14. White IR, Royston P. Imputing missing covariate values for the Cox model. Statistics in medicine. 2009;28(15):1982-98.

15. Spratt M, Carpenter J, Sterne JAC, Carlin JB, Heron J, Henderson J, et al. Strategies for Multiple Imputation in Longitudinal Studies. American Journal of Epidemiology. 2010;172(4):478-87.

16. Aley KO, Martin A, McMahon T, Mok J, Levine JD, Messing RO. Nociceptor sensitization by extracellular signal-regulated kinases. The Journal of neuroscience : the official journal of the Society for Neuroscience. 2001;21(17):6933-9.

17. Nicholson R, Dixon AK, Spanswick D, Lee K. Noradrenergic receptor mRNA expression in adult rat superficial dorsal horn and dorsal root ganglion neurons. Neuroscience letters. 2005;380(3):316-21. 
18. Khasar SG, McCarter G, Levine JD. Epinephrine produces a beta-adrenergic receptor-mediated mechanical hyperalgesia and in vitro sensitization of rat nociceptors. Journal of neurophysiology. 1999;81(3):1104-12.

19. Deyama S, Katayama T, Ohno A, Nakagawa T, Kaneko S, Yamaguchi T, et al. Activation of the betaadrenoceptor-protein kinase A signaling pathway within the ventral bed nucleus of the stria terminalis mediates the negative affective component of pain in rats. The Journal of neuroscience : the official journal of the Society for Neuroscience. 2008;28(31):7728-36.

20. Koella WP. CNS-related (side-)effects of beta-blockers with special reference to mechanisms of action. European journal of clinical pharmacology. 1985;28 Suppl:55-63.

21. Boyer N, Signoret-Genest J, Artola A, Dallel R, Monconduit L. Propranolol treatment prevents chronic central sensitization induced by repeated dural stimulation. Pain. 2017;158(10):2025-34.

22. Afify EA, Andijani NM. Potentiation of Morphine-Induced Antinociception by Propranolol: The Involvement of Dopamine and GABA Systems. Frontiers in pharmacology. 2017;8:794.

23. Chen YW, Chu CC, Chen YC, Hung CH, Wang JJ. Propranolol elicits cutaneous analgesia against skin nociceptive stimuli in rats. Neuroscience letters. 2012;524(2):129-32.

24. Tchivileva IE, Lim PF, Smith SB, Slade GD, Diatchenko L, McLean SA, et al. Effect of catechol-Omethyltransferase polymorphism on response to propranolol therapy in chronic musculoskeletal pain: a randomized, double-blind, placebo-controlled, crossover pilot study. Pharmacogenetics and genomics. 2010;20(4):239-48.

25. Light KC, Bragdon EE, Grewen KM, Brownley KA, Girdler SS, Maixner W. Adrenergic dysregulation and pain with and without acute beta-blockade in women with fibromyalgia and temporomandibular disorder. The journal of pain : official journal of the American Pain Society. 2009;10(5):542-52.

26. Harkanen L, Halonen J, Selander T, Kokki H. Beta-adrenergic antagonists during general anesthesia reduced postoperative pain: a systematic review and a meta-analysis of randomized controlled trials. Journal of anesthesia. 2015;29(6):934-43.

27. Zhou L, Kwoh CK, Ran D, Ashbeck EL, Lo-Ciganic WH. Lack of evidence that beta blocker use reduces knee pain, areas of joint pain, or analgesic use among individuals with symptomatic knee osteoarthritis. Osteoarthritis Cartilage. 2019.

28. Stubbs B, Aluko Y, Myint PK, Smith TO. Prevalence of depressive symptoms and anxiety in osteoarthritis: a systematic review and meta-analysis. Age and ageing. 2016;45(2):228-35.

29. Nackley AG, Tan KS, Fecho K, Flood P, Diatchenko L, Maixner W. Catechol-O-methyltransferase inhibition increases pain sensitivity through activation of both beta2- and beta3-adrenergic receptors. Pain. 2007;128(3):199-208.

30. Neogi T, Soni A, Doherty SA, Laslett LL, Maciewicz RA, Hart DJ, et al. Contribution of the COMT Val158Met variant to symptomatic knee osteoarthritis. Annals of the rheumatic diseases. 2014;73(1):315-7.

31. Khosla S, Drake MT, Volkman TL, Thicke BS, Achenbach SJ, Atkinson EJ, et al. Sympathetic $\beta 1$ adrenergic signaling contributes to regulation of human bone metabolism. The Journal of clinical investigation. 2018;128(11):4832-42. 
32. Hardcastle SA, Gregson CL, Deere KC, Davey Smith G, Dieppe P, Tobias JH. High bone mass is associated with an increased prevalence of joint replacement: a case-control study. Rheumatology (Oxford, England). 2013;52(6):1042-51.

33. Funck-Brentano T, Nethander M, Movérare-Skrtic S, Richette P, Ohlsson C. Causal Factors for Knee, Hip, and Hand Osteoarthritis: A Mendelian Randomization Study in the UK Biobank. Arthritis \& rheumatology (Hoboken, NJ). 2019;71(10):1634-41.

34. Ferguson RJ, Prieto-Alhambra D, Walker C, Yu D, Valderas JM, Judge A, et al. Validation of hip osteoarthritis diagnosis recording in the UK Clinical Practice Research Datalink. Pharmacoepidemiology and drug safety. 2019;28(2):187-93.

35. Rahman MM, Kopec JA, Goldsmith CH, Anis AH, Cibere J. Validation of Administrative Osteoarthritis Diagnosis Using a Clinical and Radiological Population-Based Cohort. Int J Rheumatol. 2016;2016:6475318-.

36. Culliford DJ, Maskell J, Beard DJ, Murray DW, Price AJ, Arden NK. Temporal trends in hip and knee replacement in the United Kingdom: 1991 to 2006. The Journal of bone and joint surgery British volume. 2010;92(1):130-5.

37. Hawley S, Delmestri A, Judge A, Edwards CJ, Cooper C, Arden NK, et al. Total hip and knee replacement among incident osteoarthritis and rheumatoid arthritis patients within the UK Clinical Practice Research Datalink (CPRD) compared to Hospital Episode Statistics (HES): a validation study. Pharmacoepidemiology and Drug Safety. 2016;25(Supplement S3).

\section{Tables}


Table 1

Covariate balance before and after propensity score matching

\begin{tabular}{|c|c|c|c|c|c|c|}
\hline \multirow[t]{2}{*}{ Covariates } & \multicolumn{3}{|c|}{ Entire cohort } & \multicolumn{3}{|c|}{ PS matched sample } \\
\hline & $\begin{array}{l}\text { Exposed } \\
(n= \\
4,641)\end{array}$ & $\begin{array}{l}\text { Unexposed } \\
(n=9,118)\end{array}$ & SMD & $\begin{array}{l}\text { Exposed } \\
(n= \\
3,485)\end{array}$ & $\begin{array}{l}\text { Unexposed } \\
(n=3,485)\end{array}$ & SMD \\
\hline \multicolumn{7}{|l|}{$\begin{array}{l}\text { Continuous covariates; mean } \\
\text { (SD) }\end{array}$} \\
\hline Age at $\mathrm{OA}$ diagnosis & $\begin{array}{l}64.92 \\
(11.18)\end{array}$ & $\begin{array}{l}64.11 \\
(11.18)\end{array}$ & 0.071 & $\begin{array}{l}64.80 \\
(11.16)\end{array}$ & $\begin{array}{l}65.34 \\
(11.49)\end{array}$ & -0.048 \\
\hline $\begin{array}{l}\text { Index of multiple deprivation in } \\
\text { tertiles }\end{array}$ & $\begin{array}{l}5.86 \\
(2.92)\end{array}$ & $5.94(2.86)$ & -0.026 & $\begin{array}{l}5.87 \\
(2.89)\end{array}$ & $5.81(2.87)$ & 0.020 \\
\hline $\begin{array}{l}\text { Duration of ischaemic heart } \\
\text { disease/congestive cardiac } \\
\text { failure* }\end{array}$ & $\begin{array}{l}1.21 \\
(3.92)\end{array}$ & $0.83(3.43)$ & 0.101 & $\begin{array}{l}1.12 \\
(3.91)\end{array}$ & $1.28(3.82)$ & -0.042 \\
\hline Duration of hypertension* & $\begin{array}{l}4.07 \\
(6.97)\end{array}$ & $3.39(6.51)$ & 0.101 & $\begin{array}{l}4.27 \\
(7.34)\end{array}$ & $4.71(6.26)$ & -0.065 \\
\hline \multicolumn{7}{|l|}{ Categorical covariates; n (\%) } \\
\hline Male & $\begin{array}{l}2,022 \\
(43.57)\end{array}$ & $\begin{array}{l}3,937 \\
(43.18)\end{array}$ & 0.008 & $\begin{array}{l}1,489 \\
(42.73)\end{array}$ & $\begin{array}{l}1,446 \\
(41.49)\end{array}$ & -0.025 \\
\hline Non-smoker & $\begin{array}{l}2,553 \\
(55.01)\end{array}$ & $\begin{array}{l}5,203 \\
(57.06)\end{array}$ & -0.009 & $\begin{array}{l}1,985 \\
(56.96)\end{array}$ & $\begin{array}{l}2,005 \\
(57.53)\end{array}$ & -0.012 \\
\hline Current smoker & $\begin{array}{l}593 \\
(12.78)\end{array}$ & $\begin{array}{l}1,194 \\
(13.09)\end{array}$ & -0.041 & $\begin{array}{l}430 \\
(12.34)\end{array}$ & $\begin{array}{l}391 \\
(11.22)\end{array}$ & 0.035 \\
\hline Ex-smoker & $\begin{array}{l}1,239 \\
(26.70)\end{array}$ & $\begin{array}{l}2,218 \\
(24.33)\end{array}$ & 0.054 & $\begin{array}{l}900 \\
(25.82)\end{array}$ & $\begin{array}{l}910 \\
(26.11)\end{array}$ & -0.007 \\
\hline Smoking missing data & $\begin{array}{l}256 \\
(5.52)\end{array}$ & $503(5.52)$ & 0.000 & $\begin{array}{l}170 \\
(4.88)\end{array}$ & $179(5.14)$ & -0.012 \\
\hline Underweight & $\begin{array}{l}34 \\
(0.73)\end{array}$ & $66(0.72)$ & 0.001 & $\begin{array}{l}27 \\
(0.77)\end{array}$ & $21(0.60)$ & 0.021 \\
\hline Normal weight & $\begin{array}{l}1,015 \\
(21.87)\end{array}$ & $\begin{array}{l}2,056 \\
(22.55)\end{array}$ & -0.016 & $\begin{array}{l}762 \\
(21.87)\end{array}$ & $\begin{array}{l}732 \\
(21.00)\end{array}$ & 0.021 \\
\hline Pre-obese & $\begin{array}{l}1,688 \\
(36.37)\end{array}$ & $\begin{array}{l}3,128 \\
(34.31)\end{array}$ & 0.043 & $\begin{array}{l}1,235 \\
(35.44)\end{array}$ & $\begin{array}{l}1,263 \\
(36.24)\end{array}$ & -0.017 \\
\hline Obese & $\begin{array}{l}1,375 \\
(29.63)\end{array}$ & $\begin{array}{l}2,710 \\
(29.72)\end{array}$ & -0.002 & $\begin{array}{l}1,059 \\
(30.39)\end{array}$ & $\begin{array}{l}1,098 \\
(31.51)\end{array}$ & -0.024 \\
\hline BMI missing data & $\begin{array}{l}529 \\
(11.40)\end{array}$ & $\begin{array}{l}1,158 \\
(12.70)\end{array}$ & -0.040 & $\begin{array}{l}402 \\
(11.54)\end{array}$ & $\begin{array}{l}371 \\
(10.65)\end{array}$ & 0.028 \\
\hline
\end{tabular}

SMD: Standardised mean difference * Duration in years of cardiovascular comorbidities prior to index date. 


\begin{tabular}{|c|c|c|c|c|c|c|}
\hline \multirow{2}{*}{$\begin{array}{l}\text { Covariates } \\
\text { Hypertension }\end{array}$} & \multicolumn{3}{|c|}{ Entire cohort } & \multicolumn{3}{|c|}{ PS matched sample } \\
\hline & $\begin{array}{l}2,742 \\
(59.08)\end{array}$ & $\begin{array}{l}3,236 \\
(35.49)\end{array}$ & 0.486 & $\begin{array}{l}1,908 \\
(54.75)\end{array}$ & $\begin{array}{l}2,106 \\
(60.43)\end{array}$ & -0.115 \\
\hline Angina & $\begin{array}{l}473 \\
(5.19)\end{array}$ & $\begin{array}{l}672 \\
(14.48)\end{array}$ & 0.316 & $\begin{array}{l}373 \\
(10.70)\end{array}$ & $344(9.87)$ & 0.027 \\
\hline Myocardial Infarction & $\begin{array}{l}494 \\
(10.64)\end{array}$ & $251(2.75)$ & 0.320 & $\begin{array}{l}240 \\
(6.89)\end{array}$ & $192(5.51)$ & 0.057 \\
\hline Congestive cardiac failure & $\begin{array}{l}285 \\
(6.14)\end{array}$ & $231(2.53)$ & 0.178 & $\begin{array}{l}168 \\
(4.82)\end{array}$ & $162(4.65)$ & 0.008 \\
\hline Atrial fibrillation & $\begin{array}{l}594 \\
(12.80)\end{array}$ & $370(4.06)$ & 0.319 & $\begin{array}{l}341 \\
(9.78)\end{array}$ & $319(9.15)$ & 0.022 \\
\hline Stroke & $\begin{array}{l}305 \\
(6.57)\end{array}$ & $496(5.44)$ & 0.048 & $\begin{array}{l}232 \\
(6.66)\end{array}$ & $254(7.29)$ & -0.025 \\
\hline Chronic kidney disease & $\begin{array}{l}336 \\
(7.24)\end{array}$ & $730(8.01)$ & -0.029 & $\begin{array}{l}266 \\
(7.63)\end{array}$ & $298(8.55)$ & -0.034 \\
\hline Diabetes & $\begin{array}{l}462 \\
(9.95)\end{array}$ & $856(9.39)$ & 0.019 & $\begin{array}{l}365 \\
(10.42)\end{array}$ & $\begin{array}{l}392 \\
(11.25)\end{array}$ & -0.027 \\
\hline Anxiety & $\begin{array}{l}675 \\
(14.54)\end{array}$ & $\begin{array}{l}1,063 \\
(11.66)\end{array}$ & 0.085 & $\begin{array}{l}479 \\
(13.74)\end{array}$ & $\begin{array}{l}518 \\
(14.86)\end{array}$ & -0.030 \\
\hline Migraine & $\begin{array}{l}335 \\
(7.22)\end{array}$ & $498(5.46)$ & 0.072 & $\begin{array}{l}247 \\
(7.09)\end{array}$ & $265(7.60)$ & -0.020 \\
\hline Tremor & $\begin{array}{l}133 \\
(2.87)\end{array}$ & $133(1.46)$ & 0.097 & $\begin{array}{l}92 \\
(2.64)\end{array}$ & $96(2.75)$ & -0.007 \\
\hline Osteoarthritis at any other joint & $\begin{array}{l}1,736 \\
(37.41)\end{array}$ & $\begin{array}{l}2,898 \\
(31.78)\end{array}$ & 0.119 & $\begin{array}{l}1,260 \\
(36.15)\end{array}$ & $\begin{array}{l}1,276 \\
(36.61)\end{array}$ & -0.010 \\
\hline Neck or back pain & $\begin{array}{l}1,984 \\
(42.75)\end{array}$ & $\begin{array}{l}3,626 \\
(39.77)\end{array}$ & 0.061 & $\begin{array}{l}1,475 \\
(42.32)\end{array}$ & $\begin{array}{l}1,508 \\
(43.27)\end{array}$ & -0.020 \\
\hline Calcium channel blockers & $\begin{array}{l}1,248 \\
(26.89)\end{array}$ & $\begin{array}{l}1,842 \\
(20.20)\end{array}$ & 0.158 & $\begin{array}{l}949 \\
(27.23)\end{array}$ & $\begin{array}{l}1,037 \\
(29.76)\end{array}$ & -0.056 \\
\hline $\begin{array}{l}\text { ACE inhibitors/Angiotensin II } \\
\text { receptor antagonists }\end{array}$ & $\begin{array}{l}1,577 \\
(33.98)\end{array}$ & $\begin{array}{l}2,207 \\
(24.20)\end{array}$ & 0.217 & $\begin{array}{l}1,162 \\
(33.34)\end{array}$ & $\begin{array}{l}1,269 \\
(36.41)\end{array}$ & -0.064 \\
\hline $\begin{array}{l}\text { Bendroflumethiazide/Aldosterone } \\
\text { antagonists/loop diuretics }\end{array}$ & $\begin{array}{l}2,294 \\
(49.43)\end{array}$ & $\begin{array}{l}2,875 \\
(31.53)\end{array}$ & 0.371 & $\begin{array}{l}1,616 \\
(46.37)\end{array}$ & $\begin{array}{l}1,748 \\
(50.16)\end{array}$ & -0.076 \\
\hline Alfa-adrenoreceptor blockers & $\begin{array}{l}270 \\
(5.82)\end{array}$ & $378(4.15)$ & 0.077 & $\begin{array}{l}211 \\
(6.05)\end{array}$ & $214(6.14)$ & -0.004 \\
\hline Aspirin/Clopidogrel & $\begin{array}{l}2,085 \\
(44.93)\end{array}$ & $\begin{array}{l}2,140 \\
(23.47)\end{array}$ & 0.464 & $\begin{array}{l}1,347 \\
(38.65)\end{array}$ & $\begin{array}{l}1,418 \\
(40.69)\end{array}$ & -0.042 \\
\hline
\end{tabular}

SMD: Standardised mean difference * Duration in years of cardiovascular comorbidities prior to index date. 


\begin{tabular}{|c|c|c|c|c|c|c|}
\hline \multirow{2}{*}{$\begin{array}{l}\text { Covariates } \\
\text { Statins/Fibrates }\end{array}$} & \multicolumn{3}{|c|}{ Entire cohort } & \multicolumn{3}{|c|}{ PS matched sample } \\
\hline & $\begin{array}{l}1,580 \\
(34.04)\end{array}$ & $\begin{array}{l}2,311 \\
(25.35)\end{array}$ & 0.191 & $\begin{array}{l}1,108 \\
(31.79)\end{array}$ & $\begin{array}{l}1,213 \\
(34.81)\end{array}$ & -0.064 \\
\hline
\end{tabular}

Table 2

The association between $\beta$-adrenoreceptor blocking drug prescription and knee or hip joint replacement

\begin{tabular}{|c|c|c|c|c|c|c|}
\hline Outcomes & Exposed & Events & $\begin{array}{l}\text { Person- } \\
\text { time } \\
\text { (years) }\end{array}$ & $\begin{array}{l}\text { Event rate }(95 \% \mathrm{Cl}) / \\
1,000 \text { person-years }\end{array}$ & $\begin{array}{l}\text { Model } 1 \\
\text { HR (95\% } \\
\mathrm{Cl})^{1}\end{array}$ & $\begin{array}{l}\text { Model } 2 \\
\text { HR }(95 \% \\
\mathrm{Cl})^{2}\end{array}$ \\
\hline \multirow{2}{*}{$\begin{array}{l}\text { Knee or hip } \\
\text { replacement }\end{array}$} & No & 459 & 17,637 & $26.02(23.75-28.52)$ & 1.00 & 1.00 \\
\hline & Yes & 587 & 21,894 & $26.81(24.73-29.07)$ & $\begin{array}{l}1.08 \\
(0.96- \\
1.22)\end{array}$ & $\begin{array}{l}1.11 \\
(0.98- \\
1.25)\end{array}$ \\
\hline \multirow{2}{*}{$\begin{array}{l}\text { Knee } \\
\text { replacement }\end{array}$} & No & 278 & 14,730 & $18.87(16.78-21.23)$ & 1.00 & 1.00 \\
\hline & Yes & 378 & 18,291 & $20.69(18.69-22.86)$ & $\begin{array}{l}1.12 \\
(0.96- \\
1.31)\end{array}$ & $\begin{array}{l}1.14 \\
(0.98- \\
1.34)\end{array}$ \\
\hline \multirow{2}{*}{$\begin{array}{l}\text { Hip } \\
\text { replacement }\end{array}$} & No & 119 & 2,782 & $42.77(35.74-51.19)$ & 1.00 & 1.00 \\
\hline & Yes & 151 & 3,491 & $43.25(36.88-50.73)$ & $\begin{array}{l}1.14 \\
(0.90- \\
1.45)\end{array}$ & $\begin{array}{l}1.23 \\
(0.96- \\
1.57)\end{array}$ \\
\hline \multicolumn{7}{|c|}{$\begin{array}{l}{ }^{1} \mathrm{PS} \text { matched. }{ }^{2} \text { As in model } 1 \text {, and, additionally adjusted for number of GP consultations, hospital out- } \\
\text { patient referrals, hospital admissions and number of bisphosphonate, glucosamine/chondroitin sulphate } \\
\text { prescription in the } 12 \text { month period preceding index date; total number of GP consultations for knee or hip } \\
\text { injury, non-osteoporotic fractures, hand osteoarthritis, neck or back pain or spinal degenerative diseases, } \\
\text { hypertension, duration of OA prior to index date; number of analgesic prescription between the first } \\
\text { consultation for knee/hip OA and beta-blocker prescription. }\end{array}$} \\
\hline
\end{tabular}


Table 3

The association between $\beta$-adrenoreceptor blocking drug prescription and knee or hip replacement: stratified according to drug class and drugs

\begin{tabular}{|c|c|c|c|c|c|}
\hline Exposure status & $\begin{array}{l}\text { Events } \\
\text { (n) }\end{array}$ & $\begin{array}{l}\text { Person-time } \\
\text { (years) }\end{array}$ & $\begin{array}{l}\text { Event rate } \\
\text { per } 1,000 \\
\text { person-years } \\
(95 \% \mathrm{Cl})\end{array}$ & $\begin{array}{l}\text { Model } 1 \\
\text { HR (95\% } \\
\mathrm{Cl})^{2}\end{array}$ & $\begin{array}{l}\text { Model } 2 \\
\text { HR (95\% } \\
\mathrm{Cl})^{3}\end{array}$ \\
\hline Unexposed $^{1}$ & 459 & 17,637 & $\begin{array}{l}26.02(23.75- \\
28.52)\end{array}$ & 1.00 & 1.00 \\
\hline \multicolumn{6}{|l|}{$\beta$-blocker class $\neq$} \\
\hline low lipophilic only & 13 & 444 & $\begin{array}{l}29.27(17.00- \\
50.41)\end{array}$ & $\begin{array}{l}1.17(0.67- \\
2.03)\end{array}$ & $\begin{array}{l}1.21(0.69- \\
2.13)\end{array}$ \\
\hline High lipophilic only & 7 & 157 & $\begin{array}{l}44.62(21.27- \\
93.60)\end{array}$ & $\begin{array}{l}1.75(0.83- \\
3.69)\end{array}$ & $\begin{array}{l}1.92(0.91- \\
4.08)\end{array}$ \\
\hline $\begin{array}{l}\text { Beta1selective and low } \\
\text { lipophilic }\end{array}$ & 490 & 17,165 & $\begin{array}{l}28.55(26.13- \\
31.19)\end{array}$ & $\begin{array}{l}1.15(1.01- \\
1.30)\end{array}$ & $\begin{array}{l}1.16(1.02- \\
1.32)\end{array}$ \\
\hline $\begin{array}{l}\text { Beta1selective and high } \\
\text { lipophilic }\end{array}$ & 22 & 734 & $\begin{array}{l}29.99(19.75- \\
45.55)\end{array}$ & $\begin{array}{l}1.17(0.77- \\
1.80)^{(}\end{array}$ & $\begin{array}{l}1.12(0.73- \\
1.73)\end{array}$ \\
\hline MSE and high lipophilic & 55 & 3,327 & $\begin{array}{l}16.53(12.69- \\
21.53)\end{array}$ & $\begin{array}{l}0.67(0.51- \\
0.89)\end{array}$ & $\begin{array}{l}0.69(0.52- \\
0.93)\end{array}$ \\
\hline \multicolumn{6}{|l|}{$\beta$-blocker drug name } \\
\hline Atenolol & 371 & 12,929 & $\begin{array}{l}28.70(25.92- \\
31.77)\end{array}$ & $\begin{array}{l}1.19(1.03- \\
1.36)\end{array}$ & $\begin{array}{l}1.17(1.01- \\
1.34)\end{array}$ \\
\hline Bisoprolol & 116 & 4,174 & $\begin{array}{l}27.79(23.17- \\
33.34)\end{array}$ & $\begin{array}{l}1.04(0.85- \\
1.27)\end{array}$ & $\begin{array}{l}1.17(0.95- \\
1.44)\end{array}$ \\
\hline Propranolol & 53 & 3,193 & $\begin{array}{l}16.60(12.68- \\
21.73)\end{array}$ & $\begin{array}{l}0.68(0.51- \\
0.91)\end{array}$ & $\begin{array}{l}0.71(0.53- \\
0.95)\end{array}$ \\
\hline \multicolumn{6}{|c|}{$\begin{array}{l}{ }^{1} \text { Comparison group is unexposed to } \beta \text {-blockers: }{ }^{2} \text { Propensity score matched; }{ }^{3} \text { As in model } 1 \text {, and, } \\
\text { additionally adjusted for number of GP consultations, hospital out-patient referrals, hospital admissions } \\
\text { and number of bisphosphonate, glucosamine/chondroitin sulphate prescription in the } 12 \text { month period } \\
\text { preceding index date; total number of GP consultations for knee or hip injury, non-osteoporotic fractures, } \\
\text { hand osteoarthritis, neck or back pain or spinal degenerative diseases, hypertension, duration of OA priol } \\
\text { to index date; number of analgesic prescription between the first consultation for knee/hip OA and beta- } \\
\text { blocker prescription; } ₹ \text {-blocker properties independent of each other; MSE: membrane stabilising effect. } \\
\text { Drugs from the rest of } \beta \text {-blocker class combinations were not present. }\end{array}$} \\
\hline
\end{tabular}

\section{Figures}




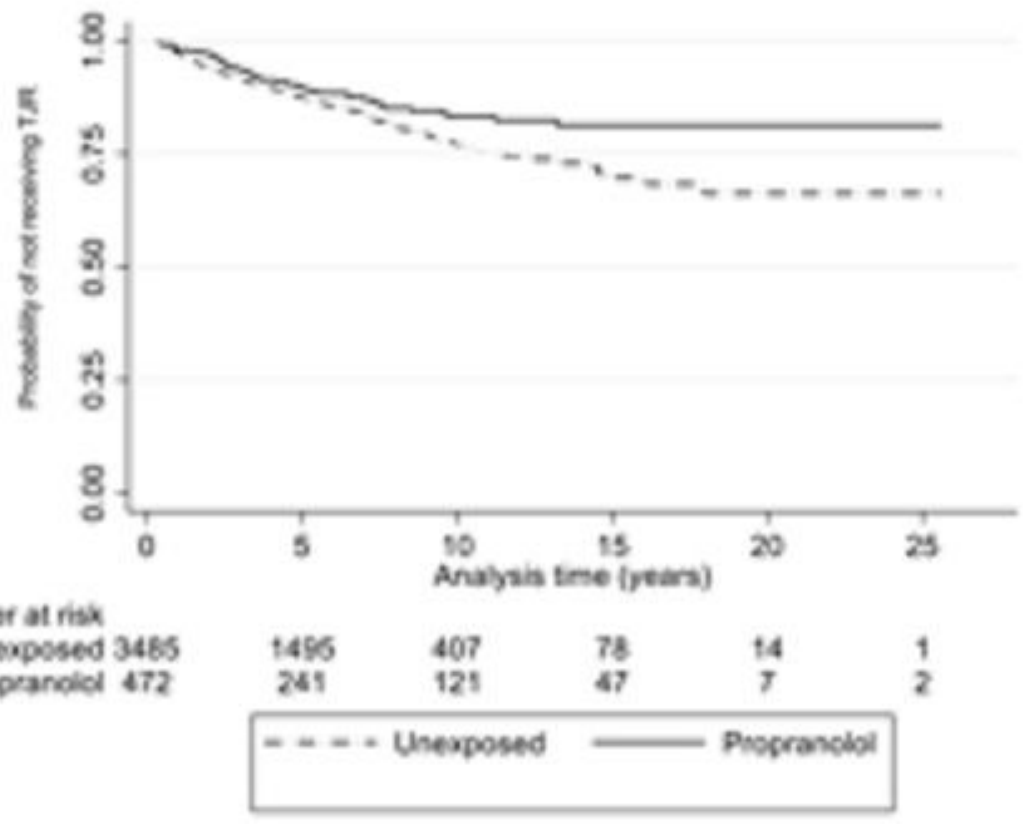

\section{Figure 1}

The association between propranolol and knee or hip replacement: Kaplan-Meier survival estimates

\section{Supplementary Files}

This is a list of supplementary files associated with this preprint. Click to download.

- supplappendixTJR.docx 